\title{
ANALISIS TINDAK TUTUR BERBASIS KORPUS PADA TAGAR TOLAK OMNIBUS LAW
}

\author{
Devi Ambarwati Puspistasari \\ Badan Pengembangan dan Pembinaan Bahasa, Indonesia \\ devi.ambarwati@kemdikbud.go.id \\ Indah Okitasari \\ Badan Pengembangan dan Pembinaan Bahasa, Indonesia \\ indah.okitasari@kemdikbud.go.id
}

Accepted: 2020-12-06, Approved: 2020-12-25 , Published: 2020-01-18

\section{ABSTRACT}

The purpose of this study is to find out the discursive portrayal of the hashtag "tolakomnibuslaw" on Twitter, which reveals rejection of the Job Creation Law by applying the synergy of linguistic corpus method and illocutionary speech act analysis. The data of this research is a corpus based taken from the utterances of Twitter users who use the hashtag of Omnibus Law Rejection (\#tolakomnibuslaw) on October 8, 2020. Word lists and collocations analysis are utilized to see patterns of the hashtag used by people in expressing rejection of the Job Creation Law. Concordance is used to lean more the analysis of speech acts and study the data. The result show that there are 38 styles of the hashtag use. Most of them is the use of noun behind the hashtag "tolakomnibuslaw". In addition, there are also five common topic hashtags included the hashtag "tolakomnibuslaw". From the perspective of speech acts, there are five types of speech acts that appear and are dominated by assertive speech and forms of criticism against government effort.

Keywords: linguistic corpus; social media; speech acts

\begin{abstract}
ABSTRAK
Tujuan penelitian ini adalah mengetahui representasi diskursif tanda pagar (tagar) "tolakomnibuslaw" pada tuturan tertulis (cuitan) di Twitter yang mengekspresikan penolakan terhadap UU Cipta Kerja dengan menerapkan sinergi metodologi korpus linguistik dan analisis tindak tutur ilokusi. Data dalam penelitian ini adalah korpus yang diambil dari tuturan pengguna Twitter yang menggunakan tagar Tolak Omnibus Law (\#tolakomnibuslaw) pada tanggal 8 Oktober 2020. Analisis pada daftar kata dan kolokasi digunakan untuk melihat pola penggunaan tagar Tolak Omnibus Law dalam mengekspresikan penolakan UU Cipta Kerja. Selanjutnya konkordans digunakan untuk memperdalam analisis tindak tutur dan melihat data secara kualitatif. Berdasarkan hasil analisis korpus, telah ditemukan 38 pola penggunaan tagar "tolakomnibuslaw". Pola yang paling sering dipakaikapai adalah pemakai nomina dibelakang tagar "tolakomnibuslaw". Selain itu, ditemukan pula lima topic topik tagar utama yang umum disertakan Bersama bersama tagar "tolakomnibuslaw". Berdasarkan analisis data dalam sudut pandang tindak tutur, terdapat lima jenis tindak tutur yang muncul dan didominasi oleh tuturan asertif dalam bentuk kritik dan hujatan terhadap kerja pemerintah.
\end{abstract}

Kata Kunci: korpus linguistik; sosial media; tindak tutur 


\section{PENDAHULUAN}

Omnibus Law UU Cipta Kerja (Ciptaker) yang sudah disahkan pada 5 Oktober 2020 telah menuai perhatian masyarakat Indonesia dan dunia. Selain terjadinya aksi demonstrasi yang serentak terjadi di berbagai kota di Indonesia, keramaian masyarakat menanggapi UU Cipta Kerja tersebut juga terjadi di dunia maya. Hal tersebut terbukti melalui tingginya pengguna Twitter yang menyuarakan pendapat melalui komentar atau cuitan dengan tagar Tolak Omnibus Law (\#tolakomnibuslaw).

Tagar Tolak Omnibus Law sendiri menjadi topik yang paling tren di Twitter pada 8 Oktober 2020, bertepatan dengan berlangsungnya aksi demo buruh dan mahasiswa yang dilaksanakan sepermpak di Indonesia (Mujib, 2020). Jumlah cuitan dengan menggunakan tagar tersebut mencapai lebih dari satu juta cuitan. Tagar Tolak Omnibus Law berada di puncak topik yang sedang tren diikuti oleh empat tagar lainnya yang posisinya tepat berada di bawahnya, yaitu tagar Mosi Tidak Percaya di tempat ke-2,tagar Tolak RUU Cipta Kerja di tempat ke-3, tagar Gagalkan Omnibus Law di tempat ke-4, dan tagar Jegal Sampai Gagal di urutan ke-5. Tagar-tagar tersebut bahkan sudah menjadi topik paling tren bahkan sejak tanggal 5 Oktober 2020 (Purbaya, 2020).

Tagar Tolak Omnibus Law tetap berada di posisi pertama sebagai topik yang paling tren di Twitter sampai 8 Oktober 2020, saat mahasiswa dari berbagai perguruan tinggi menggelar aksi demo di depan Istana Merdeka, Jakarta Pusat. Aksi demo tersebut juga dilaksanakan serentak di berbagai kota di Indonesia oleh para mahasiswa yang ingin menyuarakan aspirasinya di depan Gedung DPRD atau pusat-pusat pemerintahan di kota masing-masing. Tujuannya, untuk mendesak pemerintah mencabut UU Cipta Kerja yang sudah disahkan tersebut (Aji, 2020).

Tagar Tolak Omnibus Law disuarakan oleh berbagai kalangan masyarakat Indonesia melalui media Twitter. Cuitan para pengguna Twitter tersebut merupakan salah satu contoh sebuah fenomena tindak tutur di media sosial yang kian marak seiring meningkatnya pengguna media sosial. Pada akhir tahun 2019, pengguna aktif Twitter di Indonesia tercatat hingga 145 juta pengguna dan diklaim sebagai negara dengan pengguna aktif harian paling besar di dunia (Clinten, 2019).

Tindak tutur di media sosial banyak membawa pengaruh bagi masyarakat (Rahmi \& Tadjuddin, 2017), bahkan bagi mereka yang tidak menggunakan media sosial. Tuturantuturan media sosial memiliki kekuatan yang sama seperti tuturan-tuturan langsung didunia nyata, baik tuturan yang berisi ekspresi-ekspresi positif, maupun negatif. Tuturan di media sosial dianggap mampu mempengaruhi dunia nyata, bahkan mampu membawa penuturnya menjalani proses hukum. Salah satu contohnya tuturan yang membawa dampak hukum adalah tuturan perundungan siber (Rifauddin, 2016), (Hidajat et al., 2015), (Rahayu, 2013).

Media sosial adalah dunia siber yang dapat mempertemukan siapa saja dan kapan saja tanpa harus bertatap muka. Ciri khas ini menyebabkan potensi perundungan siber di media 
sosial sangat tinggi. Meski masyarakat Indonesia sudah dilindungi oleh UU ITE, tetapi fakta menunjukkan bahwa perundungan siber ada, terjadi, dan berdampak luas (Kususmawardhani et al., 2019). Telah banyak kajian kebahasaan, khususnya forensik kebahasaan, yang memaparkan banyak bukti tuturan media sosial yang dapat membawa dampak hukum, sebagian besar mengenai pencemaran nama baik, ancaman, provokasi, dan perundungan (Puspitasari et al., 2019).

Tuturan yang dituliskan di media sosial menggunakan ragam bahasa yang dimengerti dan dipakai oleh hampir semua pengguna ruang siber. sebagian besar ahli bahasa menyebutnya sebagai "ragam" bahasa di media sosial (Atmawati, 2016). Pemakaian kata "ragam" dianggap lebih tepat, karena ragam bahasa adalah variasi bahasa menurut pemakaian, topik pembicaraan, hubungan pembicara, lawan bicara, orang yang dibicarakan, serta medium pembicaraan yang sudah sangat mengerucut yaitu media sosial (KBBI, 2016).

Sesuai dengan definisi ragam bahasa di media sosial, tentu terdapat pula ragam bahasa di media sosial yang secara khusus digunakan pada cuitan dengan tagar Tolak Omnibus Law. Dengan tanpa melihat motif tuturan dan jarak sosial para penulis cuitan dengan tagar Tolak Omnibus Law tersebut, penelitian ini bertujuan untuk mengetahui representasi diskursif tagar Tolak Omnibus Law (\#tolakomnibuslaw) pada 8 Oktober 2020 di Twitter yang berpotensi mengekspresikan provokasi dan perundungan siber dengan menerapkan sinergi metodologi koprus linguistik dan analisis tindak tutur ilokusi.
Penelitian menggunakan korpus linguistik telah banyak digunakan untuk mendapatkan gambaran global yang lebih detail terhadap data kebahasaan (Chen \& Flowerdew, 2018). Korpus linguistik telah banyak digunakan dalam penelitian pembelajaran bahasa asing, seperti bahasa Arab (Nur et al., 2016) dan bahasa Inggris (Priyono, 2016). Kedua penelitian tersebut bertujuan untuk mengetahui sudah sejauh mana dan sudah seluas apa pembelajaran bahasa asing di Indonesia. Kedua juga menyimpulkan bahwa korpus linguistik dapat dipakai untuk membuat peta penguasaan bahasa asing.

\section{Penelitian korpus linguistik lainnya yang melatarbelakangi} penelitian ini adalah penelitian tentang pemakaian sinonim dalam bahasa Inggris. Hasil penelitian tersebut menunjukkan bahwa korpus linguistik mampu memberikan data daftar kata, kolokat, dan konkordan secara terperinci (Al Fajri, 2019). Umumnya penelitian yang memanfaatkan korpus linguistik digunakan untuk menganalisis teks-teks dengan tema tertentu dan menggunakan teori analisi wacana kritis (Al Fajri, 2020). Namun tidak banyak penelitian yang mengolah data tuturan menjadi sebuah korpus linguistik (Sotillo, 2012). Hal tersebut dikarenakan sebuah tuturan umumnya tidak dituliskan, sehingga dalam penggunaannya perlu melalui tahap transkripsi.

Berbeda dengan penelitianpenelitian linguistik korpus yang sebelumnya telah dilakukan, dimana umumnya memanfaatkan teks-teks baku, seperti buku, koran, atau hasil tulisan pembelajar bahasa asing, penelitian ini menggunakan data tuturan. Penelitian ini berupaya menganalisis data tuturan yang nyata 
digunakan oleh masyarakat Indonesia melalui piranti korpus linguistik.

Salah satu data tuturan yang sudah tersedia dalam bentuk tulis adalah tuturan media sosial. Data ini memiliki kekhasan tersendiri, karena sesungguhnya data ini adalah tuturan yang ditulis atau diketik di sebuah ruang maya. Dikarena tuturan ini adalah bahasa lisan yang ditulis, maka data ini penuh dengan varian penulisan seperti penggunaan singkatan, ejaan, dan tanda baca yang tidak sesuai dengan kaidah penulisan baku pada umumnya. Dari sisi bahasa yang digunakan, tuturan media sosial dapat mencakup lebih dari satu bahasa sekaligus dalam sebuah tuturan singkat. Oleh karena keragaman tersebut, maka perpaduan analisis tindak tutur dan korpus linguistik tepat digunakan bersama.

Berkaitan dengan derasnya arus komunikasi di media sosial dan memunculkan banyak sekali tuturan, penerapan pendekatan korpus linguistik yang menggunakan sejumlah besar data bahasa dapat bermanfaat dalam memberikan kontribusi untuk memastikan objektivitas dan cakupan penuh (Charles, 2011). Korpus linguistik dapat membantu memudahkan pengolahan data bahasa dengan jumlah besar, seperti menghitung jumlah kata, melihat kecenderungan pemakaian kata, melihat klaster kata, dan lain sebagainya. Selain dalam bidang pengajaran bahasa, fiturfitur korpus tersebut dapat dimanfaatkan dalam bidang-bidang kebahasaan yang lain, seperti sosiolinguistik dan forensik linguistik, khususnya kepengarangan.

Selain itu, signifikansi statistik dari penerapan korpus linguistik dapat membantu mencari tingkat keumuman temuan penelitian dan kesimpulan (Chen \& Flowerdew, 2018). Selain itu, korpus linguistik juga dapat meningkatkan "kepercayaan empiris" penelitian dengan menggunakan data bahasa dalam skala luas dan memberikan kredibilitas dan validitas untuk analisis (Charles, 2011).

Selain itu, signifikansi statistik dari penerapan korpus linguistik dapat membantu mencari tingkat keumuman temuan penelitian dan kesimpulan (Chen \& Flowerdew, 2018). Selain itu, korpus linguistik dapat meningkatkan "kepercayaan empiris" penelitian dengan menggunakan data bahasa dalam skala luas dan memberikan kredibilitas dan validitas untuk analisis (Charles, 2011).

Penelitian ini juga mengacu pada gagasan Austin dan Searle (dalam Leech, 2016) mengenai teori tindak tutur (Speech Act Theory) dan gagasan Herring (Dresner \& Herring, 2010) tentang komunikasi daring. Teori tindak tutur merupakan taksonomi praktis yang telah digunakan dalam studi pemrosesan bahasa alami dan komunikasi dimediasi komputer (Clancy \& O'Keeffe, 2015). Selanjutnya, teori tindak tutur memungkinkan peneliti untuk menjelaskan makna yang dimaksudkan dari pesan yang diidentifikasi dan dikodekan sebagai tindakan ilokusi (Meiarni, 2017).

Setelah mengklasifikasikan
ujaran menjadi performatif dan konstatif, serta membagi tindak tutur menjadi tindakan lokusi, ilokusi, dan perlokusi. Konsep dan taksonominya diperluas oleh Searle (dalam Leech, 2016), yang mengusulkan aturan konstitutif dan memperluas gagasan Austin tentang penyerapan dengan 
menyatakan bahwa kinerja tuturan melibatkan tindakan penuturnya. Dengan mengembangkan karya Austin, Searle memperkenalkan perbedaan antara arti kata atau kalimat literal dan makna ucapan pembicara. Bagi Searle (dalam Leech, 2016), produksi sebuah kata atau kalimat dalam tindak tutur merupakan unit dasar informasi linguistik. Selanjutnya ia membagi tuturan ilokusi menjadi lima kategori, yaitu asertif, direktif, komisif, ekspresif, dan deklaratif.

Gagasan kunci berikutnya yang relevan dengan penelitian ini adalah komunikasi daring. Herring (Dresner \& Herring, 2010) mengemukakan, komunikasi daring mengacu pada "membaca, menulis, dan berkomunikasi melalui jaringan komputer". Ia juga membedakan komunikasi daring sinkron (peserta berpartisipasi secara bersamaan dalam obrolan) dan komunikasi daring asinkron (peserta masuk pada waktu yang berbeda untuk mengobrol). Dalam hal ini, tagar Tolak Omnibus Law dalam penelitian ini termasuk dalam kategori asinkron.

Tagar Tolak Omnibus Law dalam penelitian ini digunakan sebagai pusat pencarian data tuturan yang kemudian diolah menjadi korpus linguistik menggunakan perangkat pengolah korpus, Antconc 3.5.8 (Anthony, 2015). Melalui hasil pengolahan korpus tersebut diketahui pola penggunaan tagar Tolak Omnibus Law dalam mengekspresikan penolakan terhadap UU Cipta Kerja dan jenis-jenis tindak tutur yang muncul, serta dominasi tuturannya.

\section{METODE}

Penelitian ini adalah penelitian kualitatif dengan melibatkan peneliti sebagai instrumen penelitian dan memanfaatkan korpus linguistik hasil pengolahan data tuturan Twitter dengan tagar Tolak Omnibus Law (\#tolakomnibuslaw). Data dalam penelitian ini adalah tuturan yang dituliskan pengguna twitter dengan tagar Tolak Omnibus Law (\#tolakomnibuslaw) pada tanggal 8 Oktober 2020 yang diambil pada rentang waktu pukul 10.00 sampai dengan $22.00 \quad$ WIB. Teknik pengambilan data dalam penelitian ini menggunakan Teknik random sampling dengan menjaring serratus tuturan setiap jamnya. Jumlah keseluruhan data adalah 1.200 tuturan yang kemudian direduksi berdasarkan tiga kriteria, yaitu: isi tuturan bertema penolakan UU Cipta Kerja, bukan tuturan pengulangan, sebagian atau seluruh isi tuturan menggunakan Bahasa Indonesia.

Berdasarkan hasil reduksi, jumlah data yang dilanjutkan ke tahap analisis berjumlah 326 data tuturan, 1.373 jenis kata, dan 4.667 kata. Analisis didasarkan pada data korpus terhadap daftar kata dengan rangking tertinggi, yaitu "tolakomnibuslaw" sebanyak 380 konkordans. Data Konkordans dianalisis menggunakan teori tindak tutur untuk melihat jenis tuturan. Selain konkordans, analisis juga didasarkan pada kolokasi kata "tolakomnibuslaw" untuk melihat pola penggunaan tagar Tolak Omnibus Law (\#tolakomnibuslaw) di Twitter.

Dalam penelitian ini, analisis data kualitatif dilakukan dengan mengkonfirmasi hasil pengolahan piranti korpus dengan analisis tindak tutur. Langkah-langkah analisis data dalam penelitian ini adalah reduksi data, tabulasi data, penyajian data, triangulasi data, dan penarikan kesimpulan. 
Penarikan kesimpulan dari hasil pengolahan piranti korpus adalah untuk menjawab pertanyaan penelitian pertama mengenai pola tuturan yang dominan pada penggunaan tagar "tolakomnibuslaw". Sedangkan penarikan kesimpulan kedua didasarkan pada hasil analisis tindak tutur terhadap data tuturan untuk mengetahui jenisjenis tindak tutur yang muncul pada tagar "tolakomnibuslaw".

\section{HASIL DAN PEMBAHASAN}

Pola Penggunaan Tagar Tolak Omnibus Law (\#tolakomnibuslaw)

Berdasarkan data frekuensi korpus Tolak Omnibus Law, kata "tolakomnibuslaw" menempati ranking pertama dan dipakai sebanyak 380 kali dari 1.337 daftar kata yang muncul. Hasil analisis kolokat pada tetangga kanan (R1) dan tetangga kiri (L1) telah menunjukkan adanya kecenderungan pada pola struktur pemakaian kata "tolakomnibuslaw". Penentuan pola didasarkan pada kelas kata yang menyertai tetangga kanan (R1) dan tetangga kiri (L1) pada kata "tolakomnibuslaw". Secara keseluruhan telah ditemukan sebanyak 38 pola struktur penggunaan kata "tolakomnibuslaw". Pola yang paling banyak digunakan adalah penyertaan nomina sebelum kata "tolakomnibuslaw". Berikut adalah tabel daftar lima prosentase tertinggi pola struktur yang paling sering digunakan.

Tabel 1. Pola Struktur Pemakaian Kata "tolakomnibuslaw"

$$
\begin{aligned}
& \text { Keterangan: } \\
& \mathrm{u}=\text { kata "tolakomnibuslaw" } \\
& \mathrm{n} \quad=\text { nomina } \\
& \mathrm{p} \quad=\text { preposisi } \\
& \mathrm{a} \quad=\text { adjektiva } \\
& \mathrm{v} \quad=\text { verba } \\
& \mathrm{adv}=\text { adverbia }
\end{aligned}
$$

\begin{tabular}{|c|l|r|}
\hline Peringkat & \multicolumn{2}{|c|}{ Pola } \\
\hline 1 & $(\mathrm{n}+\mathrm{X})$ & $11 \%$ \\
\hline 2 & $(\mathrm{n}+\mathrm{X}+\mathrm{p})$ & $11 \%$ \\
\hline 3 & $(\mathrm{X}+\mathrm{v})$ & $7 \%$ \\
\hline 4 & $(\mathrm{n}+\mathrm{X}+\mathrm{a})$ & $7 \%$ \\
\hline 5 & $(\mathrm{n}+\mathrm{X}+\mathrm{adv})$ & $7 \%$ \\
\hline
\end{tabular}

Dari sisi tetangga kiri (L1), pola tuturan yang muncul pada A12 didominasi oleh nomina yang diikuti kata "tolakomnibuslaw". Banyak tuturan yang diekspresikan menggunakan kata "rakyat" untuk mengekspresikan penolakan UU Cipta Kerja. Selain kata "rakyat", nomina yang sering dipakai antara lain Indonesia, demo, pejuang, dan mahasiswa. Berikut adalah beberapa contoh pola $(n+X)$. 
Tabel 2. Contoh Pola $(n+X)$

\begin{tabular}{rrrl}
\hline A.111 & Rakyat & \#TolakOmnibusLaw & \\
\hline A.024 & aspirasi rakyat Indonesia & \#TolakOmnibusLaw & \#MakzulkanRezim \\
\hline A.037 & suara rakyat Indonesia & \#TolakOmnibusLaw & \\
\hline A.082 & Mau ikutan demo & \#TolakOmnibusLaw & !!!!!! \\
\hline A.028 & Panjang Umur Perjuangan & \#TolakOmnibusLaw & $\ldots$ \\
\hline A.293 & Hidup Mahasiswa & \#TolakOmnibusLaw & \\
\hline A.016 & 6 hari kerja dalam 1 minggu & \#TolakOmnibusLaw & \\
\hline A.083 & perkuat massa & \#TolakOmnibusLaw & $! !$ \\
\hline A.156 & stay safety manteman & \#TolakOmnibusLaw & \#MosiTidakPercaya \\
\hline
\end{tabular}

Dari sisi tetangga kiri (L1), pola $(n+X)$ umumnya muncul dengan diakhiri dengan tanda baca tagar (\#) yang diikuti kata. Tagar yang sering ditemukan antara lain tagar Mosi Tidak Percaya, tagar Tolak RUU Cipta Kerja, tagar Gagalkan Omnibus, dan tagar Jegal Sampai Gagal, serta tagar-tagar yang mencerminkan sifat kedaerahan atau kelompok.

Selain tagar, itemukan pula pola $(n+X)$ yang diakhiri dengan tanda baca lain, yaitu satu atau beberapa tanda seru (!), satu atau beberapa tanda titik (.), satu atau beberapa tanda tanya (?), dan satu atau beberapa tanda koma (,). Tanda baca tersebut berfungsi sebagai penekanan terhadap tuturan yang diungkapkan. Hal tersebut tampak pada pemakaian tanda seru dan tanda titik yang jumlahnya umumnya lebih dari satu. Pemakaian tanda baca secara berlebih merupakan ekspresi perasaan penutur terhadap penolak UU Cipta Kerja. Berikut adalah daftar tagar L1 dan R1 pada pola $(n+X)$.

Tabel 3. Daftar Kata R1 dan L1 dari pada Pola $(n+X)$.

\begin{tabular}{|c|c|c|c|}
\hline Topik & R1 & L1 & Topik \\
\hline $\begin{array}{r}\text { Kedaerahan / } \\
\text { tempat }\end{array}$ & $\begin{array}{r}\text { Jakarta, } \\
\text { Magelang, Jambi }\end{array}$ & $\begin{array}{l}\text { \#TolakUUCiptaKerjaa, } \\
\text { \#MosiTidakPercaya, } \\
\text { \#OmnibusLawSampah, } \\
\text { \#BatalkanOmnibusLaw, } \\
\text { \#JegalSampaiGagal, } \\
\text { \#RakyatMenolakUuOmniBusLaw, } \\
\text { \#rakyatmenolakUOL, } \\
\text { \#BigUglyLaw, } \\
\text { \#CabutOmnibusLaw, }\end{array}$ & $\begin{array}{l}\text { Penolakan UU } \\
\text { Cipta Kerja }\end{array}$ \\
\hline $\begin{array}{r}\text { Berkaitan } \\
\text { dengan aksi } \\
\text { demonstrasi }\end{array}$ & $\begin{array}{r}\text { demo, } \\
\text { perjuangan, } \\
\text { perlawanan, } \\
\text { kejayaan, massa, }\end{array}$ & $\begin{array}{l}\text { \#RIPDemokrasi, } \\
\text { \#MenangkanPancasila, }\end{array}$ & \\
\hline
\end{tabular}




\begin{tabular}{|c|c|c|c|}
\hline Mahasiswa & $\begin{array}{r}\text { demokrasi, DPR, } \\
\text { aksi } \\
\text { mahasiswa, } \\
\text { kawan, manteman, }\end{array}$ & $\begin{array}{l}\text { \#DPRPengkhianatRakyat, } \\
\text { \#GakPercayaRezimLagi } \\
\text { \#RezimPenjahatKonstitusi } \\
\text { \#ReformasiDikorupsi, } \\
\text { \#MakzulkanRezi, } \\
\text { \#RakyatAdilMakmur, } \\
\text { \#RakyatPekerja \#PoldaNTT, } \\
\text { \#temuikami }\end{array}$ & $\begin{array}{l}\text { Kritik kepada } \\
\text { DPR / } \\
\text { pemerintah }\end{array}$ \\
\hline \multirow[t]{3}{*}{$\begin{array}{r}\text { Kata benda } \\
\text { lain yang } \\
\text { muncul }\end{array}$} & $\begin{array}{r}\text { minggu, } \\
\text { jalan, gerak }\end{array}$ & $\begin{array}{l}\text { \#JokowiBiangOmnibuslaw, } \\
\text { \#JokowiKalut, } \\
\text { \#SaatnyaJokowiTurun } \\
\text { \#JokowiPolPotIndonesia, } \\
\text { \#JokowiTurun, } \\
\text { \#GakPercayaJokowi, } \\
\text { \#SuratiPresiden }\end{array}$ & $\begin{array}{l}\text { Kritik kepada } \\
\text { Jokowi }\end{array}$ \\
\hline & & $\begin{array}{l}\text { \#masyarakat, \#DemoBuruh, } \\
\text { \#Mahasiswa, } \\
\text { \#MahasiswaBergerak, \#kaltim, } \\
\text { \#magelangbergerak, } \\
\text { \#AcehBaratDaya, } \\
\text { \#Jambi,\#SlemanHijau } \\
\text { \#BebaskanKawanKami, } \\
\text { \#fahamkan, \#KeongSawah, } \\
\text { \#PolusiUdara, } \\
\text { \#StopPolisiAnarkis, \#MataNajwa }\end{array}$ & $\begin{array}{l}\text { Kelompok / } \\
\text { kedaerahan }\end{array}$ \\
\hline & & & $\begin{array}{l}\text { Tagar lain yang } \\
\text { muncul }\end{array}$ \\
\hline
\end{tabular}

Nomina yang muncul pada L1 dapat dikategorikan setidaknya dalam enam jenis, yaitu nomina yang berhubungan dengan kelompok umum seperti kata rakyat dan Indonesia, nomina yang menunjukkan kedaerah dengan munculnya nama-nama kota, nomina yang erat kaitannya dengan kegiatan atau aksi demonstrasi, dan nomina yang erat derkaitan dengan mahasiswa. Selain itu muncul pula nomina-nomina lain yang apabila dilihat dalam kalimat lengkap adalah bentuk penolakan UU Cipta kerja dan dukungan atas aksi demontrasi. Berdasarkan data kolokat, kata rakyat adalah kata benda dengan frekuensi pemakaian yang paling 
tinggi, yaitu peringkat ke-12 dengan 26 pemakaian tepat sebelum \#tolakomnibuslaw (L1). Kata rakyat digunakan sebagai ekspresi penolakan terhadap UU Cipta kerja.

Sedangkan pada R1, tagar Tolak Omnibus Law diikuti oleh berbagai macam tagar. Tagar tersebut dapat disimpulkan terbagi dalam lima macam topik. Topik tagar yang paling banyak frekuensinya adalah tagar yang secara jelas menyuarakan penolakan UU Cipta Kerja, tagar permintaan untuk menurunkan Presiden Joko Widodo atau kritik yang ditujukan khusus Presiden Joko Widodo, dan tagar yang ditujukan secara khusus untuk mengkritik DPR. Selain tiga tagar tersebut, muncul pula tagar yang bertema kelompok atau kedaerahan, seperti tagar Mahasiswa (\#Mahasiswa, \#MahasiswaBergerak) yang menadakan dukungan aksi demonstrasi mahasiswa, seklaigus penanda cuitan tersebut ditulis oleh mahasiswa. Terdapat pula tagar-tagar lain yang berkaitan dengan aksi demo 8 Oktober 2020, seperti kritik terhadap sikap polisi dalam mengamankan aksi demo melalui tagar Polisis Anarkis (\#polisisAnarkis).

\section{Tujuan Pertuturan}

Berdasarkan analisis data dalam sudut pandang tindak tutur, ditemukan ada lima jenis tindak tutur yang muncul, yaitu asertif, direktif, komisif, ekspresif, dan deklaratif. Hasil analisis pada koknkordans menunjukkan kecenderungan tingginya tuturan asertif sebagai bentuk ekspresi penolakan terhadap UU Cipta Kerja. Tuturan Asertif mendominasi dengan persentase terbesar sebesar $40 \%$. Data ini membuktikan bahwa ekspresi penolakan terhadap UU Cipta kerja melalui cuitan dengan menyertakan tagar Tolak Omnibus Law paling banyak diungkapkan dalam bentuk kalimat pernyataan

Tabel 4. Jumlah Tuturan Ilokusi

\begin{tabular}{|c|c|}
\hline Tuturan Ilokusi & A12 \\
\hline asertif & $38 \%$ \\
\hline direktif & $30 \%$ \\
\hline ekspresif & $21 \%$ \\
\hline komisif & $11 \%$ \\
\hline deklaratif & $0 \%$ \\
\hline
\end{tabular}

Tabel 5. Contoh Tuturan Asertif

\begin{tabular}{ll}
\hline A.004 & $\begin{array}{l}\text { Aliansi Labuan Memanggil Menolak Keras OmniBusLaw. Kami Tegas } \\
\text { \#TolakOmnibusLaw. \#MosiTidakPercaya \#JegalSmapaiGagal } \\
\text { \#LabuanMemanggil }\end{array}$ \\
\hline A.065 & $\begin{array}{l}\text { Aliansi Mahasiswa Garut Gerudug DPRD Garut Tolak UU Ciptaker. } \\
\text { \#TolakOmnibusLaw \#TolakUUCiptaKerja \#UUCiptaKerja } \\
\text { \#DPRDGarut }\end{array}$ \\
\hline A.077 & $\begin{array}{l}\text { Rakyat bersatu singkirkan kepala batu! Rakyat \#TolakOmnibusLaw } \\
\text { \#MosiTidakPercaya \#RakyatMenolakOmnibusLaw }\end{array}$ \\
\hline
\end{tabular}

BAHTERA : Jurnal Pendidikan Bahasa dan Sastra, Volume Januari 2021 
A.259 Gak ada waktu buat ngeladenin masturbasi intelektualitas mereka. Draf resminya aja belom ada. Dari niat proses pengesahannya jahat, isinya udah pasti jahat. \#TolakOmnibusLaw \#MosiTidakPercaya

\section{A.124 SKANDAL LEGISLASI}

Proses pembuatan Omnibus Law, yang tidak transparan, melanggar UU 12 Tahun 2011 tentang pembentukan undang-undang. \#TolakOmnibusLaw

\section{A.012 DPR RI PENGHIANAT \#tolakomnibuslaw}

Tuturan asertif terikat pada kebenaran proposisi yang diungkapkan; misalnya menyatakan, memberitahukan, menyarankan, membanggakan, menyombongkan, mengeluh, menuntut, dan melaporkan (Searle, 2014). Tuturan asertif pada data seringkali muncul dalam bentuk pernyataan penolakan UU Cipta Kerja oleh suatu kelompok tertentu. Sering pula ditemuka pernyataan penolakan menggatasnamakan rakyat atau rakyat Indonesia. Ditemukan pula tuturan asertif dalam bentuk kritik dan opini terkait hal-hal yang dianggap sebagai kesalahan DPR atau pemerintah. Selain itu, pernyataan berupa hujatan yang ditujukan kepada DPR dan Presiden Joko Widodo juga menunjukkan frekuensi yang tinggi, umumnya memakai kata pengkhianat, gagal, dan bodoh. Kata "bodoh" sendiri banyak diungkapkan dalam berbagai ragam bahasa, seperti dongo, pekak, pe'a, goblok, dan lain sebagainya.
Jenis tindak tutur kedua dengan frekuensi kemunculan paling tinggi adalah tuturan direktif sebesar $30 \%$. Tindak tutur direktif berfungsi untuk membuat penutur akan melakukan sesuatu atau menimbulkan efek berupa tindakan yang dilakukan oleh penutur. Fungsi ilokusi ini misalnya: memesan, memerintah, memohon, menuntut, memberi nasehat, menyuruh, menantang, menyarankan, menganjurkan, memastikan, mengajak, mengijinkan, menawar, melarang, mendesak, memperingatkan (Leech, 2016).

Tuturan direktif yang ditemukan pada data dalam penelitian ini didominasi oleh tiga hal, yaitu ajakan untuk menolak pengesahan UU Cipta Kerja, tuntutan untuk melengserkan pemerintah (Presiden Joko Widodo dan DPR), dan saran atau ajakan yang berkaitan dengan aksi demo. Berikut adalah contoh tuturan direktif yang disertai dengan tagar Tolak Omnibus Law

Tabel 6. Contoh Tuturan Direktif

A.204 Teruntuk saudaraku sebangsa (Bangsa kesatuan) dan setanah air (Tanah air tanpa penindasan), tetap satukan tujuan, hindari konflik horizontal yg setan-setan inginkan, dan selalu saling menjaga saudara yg lain. Ayo kita LAWAN!!! \#TolakOmnibusLaw \#MOSITIDAKDIPERCAYA \#JogjaMemanggil

A.208 Mari kawan2 semua kita merapat kedepan istana...untuk menuntut hak kita di negeri yang kita cintai ini... \#TolakOmnibusLaw \#TolakUUCiptaKerja

BAHTERA : Jurnal Pendidikan Bahasa dan Sastra, Volume Januari 2021 


\begin{tabular}{ll}
\hline & \#RakyatMenolakOmnibuslaw \#MosiTidakPercayaJokowi \\
\hline A126 & $\begin{array}{l}\text { Untuk teman-teman yang turun aksi hari ini. Dari manapun kalian, tetap } \\
\text { harus hati-hati, harus saling jaga ya. Banyak intel2 yang nyamar jadi tukang } \\
\text { kopi, tukang aer, tukang ojek, dan malah berkerumun dengan massa. } \\
\text { \#TolakOmnibusLaw }\end{array}$ \\
\hline A.017 & $\begin{array}{l}\text { Jangan lupa Helm! } \\
\text { \#TolakOmnibusLaw }\end{array}$ \\
\hline
\end{tabular}

Tuturan “jangan lupa helm” yang diserta tagar Tolak Omnibus Law banyak ditemukan dan disebarkan oleh para pengguna Twitter. Tuturan tersebut mengandung makna ajakan untuk mempersiapkan keselamatan diri saat menjalankan aksi demo dengan membawa helm sebagai pelindung kepala. Namun tuturan ini juga membawa kesan bahwa diprediksi aka nada kerusuhan, sehingga para pengguna Twitter bersikap seolah saling mengingatkan. Hal tersebut terbukti melalui penelususran akun, dimana cuitan "jangan lupa bawa helm" juga banyak dituturan oleh bukan peserta demostrasi. Tuturan ini justru menjadi pemicu stigma negatif aksi demnstrasi, karena ada "kesan" kekerasan yang dibangun, meski aksi belum dimulai.

Tabel 7. Contoh Tuturan EKSPRESIF

\begin{tabular}{ll}
\hline A.057 & Jokowi GOBELOK!!!! \#TolakOmnibusLaw \#MOSITIDAKDIPERCAYA \\
\hline A.208 & $\begin{array}{l}\text { DPR'e pekok... Jokowi kabur!!! \#TolakOmnibusLaw } \\
\text { \#JokowiBiangOmnibuslaw, \#JokowiKalut , \#SaatnyaJokowiTurun }\end{array}$ \\
\hline
\end{tabular}

Selain asertif dan direktif, tuturan ekspresif juga ramai muncul dalam bentuk kekecewaan yang diikuti umpatan dan kecaman. Tuturan komisif yang ditemukan pada data dalam kajian ini didominasi oleh kaul dan sumpah untuk tetap berjuang menolak UU Cipta Kerja. Sedangkan tindak tutur deklaratif tidak ditemukan sama sekali pada semua data tuturan dalam penelitian ini.

\section{KESIMPULAN DAN SARAN}

Berdasarkan hasil analisis korpus pada tuturan dengan tagar Tolak Omnibus Law, telah ditemukan 38 pola penggunaan tagar "tolakomnibuslaw". Pola yang paling sering dipakai adalah pemakai nomina dibelakang tagar "tolakomnibuslaw". Selai itu, hasil analisis dengan piranti korpus juga menjukkan adanya kecenderungan topik yang munculnya menyertai targar Tolak Omnibus Law. Topik-topik tersebut ditandai dengan hadirnya lima jenis tagar yang dicuitkan pengguna Twitter secara berulang. Tagar yang paling tinggi frekuensinya adalah tagar yang secara jelas menyuarakan penolakan UU Cipta Kerja, tagar permintaan untuk menurunkan Presiden Joko Widodo atau kritik yang ditujukan khusus Presiden Joko Widodo, dan tagar yang ditujukan secara khusus untuk mengkritik DPR. Selain tiga tagar tersebut, muncul pula tagar yang bertema kelompok atau 
kedaerahan dan tagar-tagar lain yang berkaitan dengan aksi demo 8 Oktober 2020.

Berdasarkan analisis data dalam sudut pandang tindak tutur, terdapat lima jenis tindak tutur yang muncul dan didominasi oleh tuturan asertif dalam bentuk kritik dan hujatan terhadap kerja pemerintah. Tuturan media sosial yang diungkapkan dalam pernyataan-pernyataan negatif mampu memiliki efek yang besar hingga berlanjut di dunia nyata. Tuturan direktif mampu menggerakan massa dalam jumlah besar untuk turut berpartisipasi dalam aksi demonstrasi menolak UU Cipta Kerja pada 8 Oktober 2020. Tuturan direktif juga mempengaruhi pandangan masyarakat mengenai pengesahan UU Cipta Kerja.

Berdasarkan analisis tindak tutur pula, ditemukan dominasi tuturan asertif yang sangat berpotensi untuk dibawa ke ranah hukum dengan jerat Undang-undang ITE, dengan delik aduan pencemaran nama baik, ancaman, maupun provokasi. Tuturan asertif yang berimplikasi hukum tersebut khususnya yang ditujukan kepada Presiden Joko Widodo, DPR, dan kritik terhadap kinerja pemerintah. Masih banyak pengguna akun Twitter yang dengan leluasa menyatakan pendapat, tanpa pemahaman yang mendalam mengenai implikasi hukum bertutur di sosial media. Melalui hasil penelitian ini diharapkan dapat memberikan wawasan akan pentingnya mengetahui implikasi hukum dalam menuliskan pendapat di sosial media.

Melalui hasil penelitian ini diharapkan ada penelitian lanjutan mengenai tuturan yang mengandung provokasi dengan korpus yang lebih besar. Melalui penelitian tersebut diharapkan dapat diperoleh deskripsi lengkap dan pemetaan pola-pola tuturan provokasi di media sosial. Lebih lanjut lagi, direkomendasikan kepada pihak-pihak yang berkepentingan dapat memanfaatkan penelitian ini untuk menetukan kata kunci dalam penelitian digital forensik.

\section{DAFTAR PUSTAKA}

Aji, M. R. (2020). Ini Situasi Demo Tolak Omnibus Law di 5 Kota Besar Pada Kamis, 8 Oktober 2020.

Tempo.

https://nasional.tempo.co/read/139 4301/ini-situasi-demo-tolakomnibus-law-di-5-kota-besarpada-kamis-8-oktober-2020

Al Fajri, M. S. (2019). Skinny, Slim, dan Thin: Analisis Berbasis Korpus Kata Sifat Identik dan Implikasinya pada Pengajaran Bahasa Inggris. Ranah: Jurnal Kajian Bahasa, 8(1), 19-32. https://doi.org/Doi: 10.26499/rnh.v8i1.894

Al Fajri, M. S. (2020). The Construction of Indonesian Muslims and Islam in Australian Newspapers: A Corpus-Assisted Critical Discourse Analysis. Discourse and Interaction, 13(1), 5-24. https://doi.org/https://doi.org/10.5 817/DI2020-1-5

Anthony, L. (2015). Laurence Anthony's AntConc. In AntCont Software (3.5.8). Antcont Software.

Atmawati, D. (2016). Penggunaan Bahasa Pada Media Sosial (the Use of Language in Social Media). International Seminar Prasasti III: Current Research In Linguistics.

Charles, M. (2011). The Routledge Handbook of Corpus Linguistics. System. https://doi.org/10.1016/j.system.2 $\underline{011.01 .004}$

Chen, M., \& Flowerdew, J. (2018). Introducing data-driven learning to $\mathrm{PhD}$ students for research writing 
purposes: A territory-wide project in Hong Kong. English for Specific Purposes. https://doi.org/10.1016/j.esp.2017. 11.004

Clancy, B., \& O'Keeffe, A. (2015). Pragmatics. In The Cambridge Handbook of English Corpus Linguistics.

https://doi.org/10.1007/97811397 64377.014

Clinten, B. (2019). Pengguna Aktif Harian Twitter Indonesia Diklaim Terbanyak. Kompas. https://tekno.kompas.com/read/20 19/10/30/16062477/penggunaaktif-harian-twitter-indonesiadiklaim-terbanyak

Dresner, E., \& Herring, S. C. (2010). Functions of the nonverbal in CMC: Emoticons and illocutionary force. Communication Theory. https://doi.org/10.1111/j.14682885.2010.01362.x

Hidajat, M., Adam, A. R., Danaparamita, M., \& Suhendrik, S. (2015). Dampak Media Sosial dalam Cyber Bullying. ComTech: Computer, Mathematics and Engineering Applications. https://doi.org/10.21512/comtech. v6i1.2289

KBBI. (2016). Kamus Besar Bahasa Indonesia ( KBBI ). In Kementerian Pendidikan dan Budaya.

Kususmawardhani, F., Khotimah, H., \& Puspitasari, D. A. (2019). Kajian Bahan Kebijakan Cyberbullying Di Media Sosial Pada Pelajar Indonesia. Tidak Diterbitkan.

Leech, G. (2016). Principles of Pragmatics. In Principles of Pragmatics. https://doi.org/10.4324/97813158 35976
Meiarni, I. (2017). Tindak Tutur Ilokusi Dalam Upacara Adat Perkawinan Masyarakat Muna Sulawesi Tenggara (Studi Penelitian Etnografi Komunikasi). BAHTERA: Jurnal Pendidikan Bahasa Dan Sastra, 16(1), 28-38. https://doi.org/https://doi.org/10.2 1009/BAHTERA.161.003

Mujib, I. L. (2020). UU Cipta Kerja Gol, Tagar Tolak Omnibus Law Trending Topic di Twitter. IDN Times.

https://www.idntimes.com/news/i ndonesia/ilyas-listianto-mujib1/uu-cipta-kerja-gol-tagar-tolakomnibus-law-trending-topic-ditwitter

Nur, H., Fazlurrahman, \& Fauziah, F. (2016, Oktober 15). Linguistik Korpus Dalam Kajian Dan Pembelajaran Bahasa Arab Di Indonesia. Prosiding Konferensi Nasional Bahasa Arab II, 385-393.

Priyono. (2016, Februari). Prospek Penggunaan Korpus untuk Studi Kebahasaan dan Proses Pembelajaran Bahasa Kedua. Jurnal Ilmu Pendidikan, 2(6). 10.17977/jip.v6i2.703

Purbaya, G. f. (2020). Trending Tagar TolakOmnibusLaw di Twitter Tidak Pengaruhi RUU Ciptaker di Sahkan. Jakpus News. https://jakpusnews.pikiranrakyat.com/nasional/pr44803252/trending-tagartolakomnibuslaw-di-twitter-tidakpengaruhi-ruu-ciptaker-di-sahkan

Puspitasari, D. A., Kususmawardhani, F., \& Khotimah, H. (2019). Analisis Forensik Lingusitik Ujaran Provokasi Pelajar Penyebab Tawuran. Tidak Diterbitkan.

Rahayu, F. S. (2013). Cyberbullying Sebagai Dampak Negatif Penggunaan Teknologi Informasi. 
Jurnal Sistem Informasi. https://doi.org/10.21609/jsi.v8i1.3 21

Rahmi, R., \& Tadjuddin, S. (2017). Strategi Kesantunan Positif Dalam Tindak Tutur Pada Novel Bidadari-Bidadari Surga Karya Tere Liye. BAHTERA: Jurnal Pendidikan Bahasa Dan Sastra, 16(2), 55-67. https://doi.org/https://doi.org/10.2 1009/BAHTERA.162.05

Rifauddin, M. (2016). Fenomena Cyberbullying pada Remaja (Studi
Analisis Media Sosial Facebook). Khizanah Al-Hikmah : Jurnal Ilmu Perpustakaan, Informasi, Dan Kearsipan.

Searle, J. R. (2014). What Is A Speech Act? In M. Black \& W. P. Alston (Eds.), Philosophy in America (p. 307). Cornell University Press.

Sotillo, S. M. (2012). Illocutionary acts and functional orientation of SMS texting in SMS social networks. Aspects of Corpus Linguistics: Compilation, Annotation, 